\title{
GROWTH PROSPECTS OF E-RETAILING IN ELECTRONIC GOODS MARKETS
}

\author{
Gunjan Malhotra ${ }^{1}$, Ranjana Aggarwal ${ }^{2}$ \\ ${ }^{1}$ Institute of Management Technology, Ghaziabad, Raj Nagar, Hapur Road, Ghaziabad-201001, Uttar \\ Pradesh, India
}

*Corresponding Author: Gunjan Malhotra

Corresponding Author Email: gmalhotra@imt.edu

Article Received: 02-04-19

Accepted: 30-04-19

Published: 05-05-19

Licensing Details: Author retains the right of this article. The article is distributed under the terms of the Creative Commons Attribution-NonCommercial 4.0 Licence (http://www.creativecommons.org/licences/by-nc/4.0/) which permits non-commercial use, reproduction and distribution of the work without further permission provided the original work is attributed as specified on the Journal open access page.

\begin{abstract}
E-retailing has emerged as a significant player in the retail industry in India. The major cutthroat competition happens between Flipkart, Amazon, and Snap deal. These merchants have a significant competitive edge on electronic goods over other merchants in Indian online shopping portals. Thus, the purpose of this paper is to understand and analyses the universal perception and satisfaction quotient of customers in India concerning to the purchase of electronic goods via these e-commerce merchants. We have used hypothesis testing and analysis of variance to understand customer satisfaction and customer perception. The results show that overall customer satisfaction is the highest for Flipkart. Also, the physical appeal and the quality of the product are the main reasons which impact the customer's perception toward not shopping online. This study is original in itself because it is limited to the purchase of electronic goods only from the emerging e-retail merchants- Flipkart, Snap deal, and Amazon in India.
\end{abstract}

Key Words: Electronic Goods; E-retail; Flipkart; Amazon; Snapdeal; India

\section{INTRODUCTION}

E-retailing is the significant component of the e-commerce industry. E-commerce provides a unique shopping experience to the customers by helping them to explore different online retail portals, comparing the products for the lowest possible cost, and eventually, customers buy the product that provides them the maximum satisfaction (Lee and Tan, 2003). Although retail e-commerce markets are enjoying incredible growth, it is unlikely to significantly 
displace the traditional brick-and-mortar retailing experience for the customers in future (Kolesar and Wayne, 2000). The e-commerce gives noteworthy control to shoppers by providing simple-to-use requesting frameworks that permit customers to pick and demand items as per their particular specifications (Wei et al. 2011). Moreover, former brick-andmortar retailers have increased consumer's loyalty by designing offline attributes and belief only online retail brands have provided channel interdependencies by creating successful multichannel retailing systems (Swoboda, Weindel, and Schramm-Klein, 2016).

The brick-and-mortar business alludes to an organization that has structures, creation offices, or store for operations (InvestorWord, 2016). This conventional brick-and-mortar (a traditional "street-side" business that deals with its customers face to face in an office or store that the company owns or rents) shops have given pace to the e-retailing shops. Therefore, the brick-and-mortar businesses find it difficult to compete with web-based companies because the latter usually have lower operating cost, and higher flexibility (Investopedia, 2016). Marketing on the internet allows visitor (likely customers) to access the website of the company and go through a virtual catalog of different products and services offered by the company (Bhakkad, 2012). This proposition of getting the needs or desires fulfilled at the convenience of your finger-tips have become popular.

E-commerce has gained immense popularity in Indian markets as it comprises of trading with products as well as services. Online business in India tremendously grown and have become a billion-dollar baby for India. The digital impact on Indian consumer spending is expected to be USD150 billion. Most of the online shopping websites compete with each other to capture the market share (Gadgets Now, 2014). The significant players in the Indian online industry are Flipkart, Amazon, and Snapdeal. There are some other smaller but relatively successful players like PayTM, Shopclues, Firstcry, etc. in the Indian market. Further, due to the massive amount of investment flowing into these online organizations, it becomes vital for them to spend on the different and valuable customer preference angles to increase their company's sale and presence in the industry. As the world looks towards India, and its online transformation, every site hopes to catch the heart and hard plate of the advanced Indian buyer (Prashar, Sahay and Panda, 2014). That has considerably impacted the traditional system of retailing and shifted towards electronic means or the non-store formats (Mulhern, 1997). This system has become prevalent in the Indian markets. The non-store buyers have contributed to a significant portion of the sales.

Over the time the consumers have started online shopping through their smart phones as well as browse their products of choice via the internet websites. There are several options regarding the expedited delivery that is available to the customers. One has to incur a nominal expense to avail such services. It becomes hugely lucrative and, buyers get influenced by the offers and deals provided. In this paper, therefore, an attempt is made to examine the Indian customer perception and customer satisfaction towards selected famous e-commerce merchants such as Flipkart, Amazon, and Snap deal.

\section{LITERATURE REVIEW}

Consumers demand goods and services through e-retail companies using internet or other electronic channels (Harris and Dennis, 2002). With extensive choice, consumers choose the brands that they trust. (McGoldrick, Stewart, and Watson, 2002). The electronic medium of 
doing business should change the rules of doing business itself. It saves time and cost for both the company as well as the individual online customers. Here develops trust and initial intention to purchase from online merchants (Gulam and Badhusha, 2015).

The web shopping conduct of buyers from a variety of business disciplines gained noteworthy ground throughout the years (Chan, et.al, 2003). With e-business, the shoppers have a more extensive scope of decisions for the required items from the variety of sellers. That perhaps happen as the numerous sellers have begun utilizing web destinations as shop fronts (McDonagh and Prothero, 2014). The customers have a choice to browse different websites and may buy from different sellers. That helps customers to find particularly what they want to buy. The consumers who are isolated may get an option to shop from ecommerce sites which promotes the same products with same quality but at lower prices compared to the local markets (Dunn, 2008).

E-commerce can offer most extreme accommodation to customers since they can visit different online storefronts to look at costs and make buys appropriately without going anywhere. Customers can buy products with a click of a mouse button without moving out of their home or office (Zaveri, 2008). E-business gives data on items and helps to increase cost straightforwardness by expanding openness of the customers to settle on more appropriate buying choices (Andam, 2003).

With e-trade, a community organization might no more hold imposing business model with pricing in a region even alternate contenders are remote from them, so that, the quality and the cost of merchandise will be the ultimate component for the organization to succeed (Wei, et.al. 2011). It empowers customers to perform value examination, with the goal that they can settle on more appropriate buying choices (Andam, 2003). Furthermore, with e-trade, customers can spare their time since they can have admittance to their cash from home through Internet, and work all from a desktop personal computer (PC). Additionally, exchanges can be taken care of over the Internet much faster than offline systems (Vyavhare, 2007).

Thus for web shopping or showcasing the use of technology (i.e., computer) has increased for better marketing performance. Dealers or business people plan their strategies to meet the demand of increased online shoppers (Vadivu, 2015). For the retailers - there are a few advantages, for example, - set up an online vicinity; draw in new clients; save money on operational costs; better comprehend your clients; boost brand awareness; equip customers with data; drive transformations and deals, and so on. Online product experiences validate the underlying mechanisms through which the way of representing products affect consumer responses (Overmars and Poels, 2015).

However, the impact of customers' attributes on view of shopping advantages through both electronic and physical shopping arrangements are different from each other. The impact of individual customers' attributes, for example, age, family unit wage and family structure and past practices on the shopping advantages connected with these methods of shopping (Roy, and Uusitalo, 2002). Shopping productivity enables consumers' to consider customers' who seek the best outcome and customers' who stop their information search as soon as an appropriate option is available. That includes four dimensions: time/effort savings, right purchase, money savings, and hedonic benefits from shopping (Voropanova, 2015).

Since the most recent two decades, the quantity of online customers has to a great extent 
expanded alongside the ascent of internet shopping sites (Manjunatha, 2013). The web has brought the entire world at a click of a button. Life has become occupied and quick in metros, and with expansion in nuclear families (where husband and wife both work) there is less time to buy household and additionally extravagance things. Consequently, accessibility of web has offered approaches to web shopping (Gupta, and Gandhi, 2015). Though this has not limited the online shoppers from their likelihood of complaint management when compared to consumers using traditional distance-shopping channels (Jasper and Waldhart, 2013).

Therefore, electronic commerce business is a paradigm shift. This innovation has radically changed the traditional way of doing business in India as well. In India, e-commerce has shown tremendous business growth by continuously adding internet users (Chatterjee and Ghosal, 2014). Even as online business is growing, it is beginning to create confusion to the traditional brick and mortar retail outlets as well as causing discomfort to established brands (Kumar, 2015).

The Indian consumers are conservative in purchasing goods through online shopping portals. In traditional style, people go to the market, see the items, touch them-bargains and then buy it. Although the internet shopping is superior to conventional shopping, yet the majority of the buyers decide not to do online shopping. As a result of the shaky payment and exchange frameworks, they are unable to see and touch the items physically (Sheopuri, and Sheopuri, 2015). The young generation in India has accepted and started moving from window shopping to online shopping. Few success stories of online shopping websites include Amazon, Myntra, Flipkart, Snap deal, Yepme, Olx, Jabong, FirstCry, PayTM, etc. (Gupta and Bansal, 2016). The online commerce companies such as Flipkart, Snap deal, Jabong, Amazon and many others, have intense competition among themselves due to which customers are bewildered. These dynamic capabilities that Indian consumers possess range from the very specific and identifiable to a generic set of knowledge-related to the good they intend to buy (Eriksson, 2014). The paradigm shifts in the way customers shop online has increased primarily due to attractive price deals available online. The internet penetration at lower prices, availability of low priced smart-phones, and the young population of India has facilitated and has helped to increase online commerce industry (Bhandari, N., 2015).

Moreover, the satisfaction of the consumers through online shopping has increased and their online buying behaviour from different merchants has also changed (Bama and Ragaprabha, 2016). The popularity of online shopping in India increased the convenience of the consumers to shop and bargain from their home or office. That prevented customers to buy from bricks-and-mortar shopping malls and also business-to-business online shopping has also emerged. Also few services such as plumber, carpenter, etc. are purchased online (Richa, 2012). Thus the consumer's attitudes, habits, perception and satisfaction levels have become most important for the e-retailers. (Vadivu, 2015). It refers to an individual's positive or negative evaluation of self-performance of a particular behavior (Fishbein and Ajzen, 1975). According to Fishbein and Ajzen (1975), attitude acts in four ways. Attitude helps people understand the world by simplifying input from the environment. It protects people's selfesteem by helping them to avoid the inconvenient truth. This approach enables people to adjust to the world by maximizing benefits. Finally, it allows people to express their values.

The online customer experience affects satisfaction as opposed to work (Bolar and Shaw, 2015). Also, the relationship between customer perceptions of corporate image and 
behavioral intentions of retail service quality is entirely by satisfaction ( $\mathrm{Yu}$ and Ramanathan, 2012). The customer's attitudes and desires towards internet shopping contrast usually crosswise over incomprehensible societies in India.

The behavior of consumers while shopping online are influenced by different sales promotion techniques. The online dealers cover promotional e-mails; promotional SMS, discounts; userfriendly interface; promotional pop-ups; coupons; convenience, and sales promotion influences (Sharma and Khattri, 2013). The sales promotion has adversely affected the consumers as they feel that they have been cheated number of times due to different promotional tools. This in turn has affected the brand loyalty among the consumers and in turn the sales decline which further hampers the brand image (Malik and Sachdev, 2015).

The consumer loyalty with the request satisfaction process (i.e. physical circulation quality) is an essential determinant of general consumer loyalty with the retailer, and in addition with the degree of customer maintenance delighted in by the retailer. The web retailing industry keeps on growing quickly. A few Internet retailers are, in any case, struggling to retain customers because of the abnormal state of rivalry among occupants. In spite of the fact that the purchase satisfaction is a solid pointer of customer retention, however don't have almost the same effect on customer retention directly as they have on purchase satisfaction (Rao, et.al. 2011).

\section{Conceptual Framework and Hypothesis Formulation}

Researchers studying e-commerce industry are of the opinion that the buying behaviour of the consumers are different with respect to the different websites and business plan. With the onset of the new online businesses, there has been an addition of new customers and new products with attractive offers available on different e-commerce merchant's websites. With this the competition, and rivalry among these merchants have increased more specifically for a particular type of product. This has also been justified by Porter's five forces theory. Michael Porter's theory (2008) was first developed in 1979 and later revised in 2008. Porter's model of five forces identifies and analyses competitive forces that shapes every industry can also be applied in the e-commerce industry. The model helps to determine an industry's strengths and weaknesses. Porter's five forces include: (a) high threats of substitutes, (b) high bargaining power of buyers, (c) low bargaining power of suppliers, (d) high threats of new entrants and (e) high competitive rivalry.

Porter's theory can help us to understand the e-commerce industry's progress in India. This industry is very attractive because there are no significant barriers to entry and hence, there is a threat of new entrants to the existing players. The competitive rivalry among the different ecommerce players is very high because the industry is continuously growing. The marketed products may not be differentiated. The bargaining power of the buyer is high as it is very easy for them to find any other supplier in the market. The people don't have any loyalty for the brand and they look for cheap and better products. The bargaining power of suppliers is low because the products existing in this industry are sold by many firms. It is easy to sell the products on the internet, so there are threats of substitute products. The products marketed could be sold by other firms inside or outside the industry and, the customers can look for cheaper products to the brick and mortar stores also. Therefore, we intend to study the electronic goods merchants in this industry and the most competitive players such as Flipkart, 
Snap deal, and Amazon in Indian e-retail sector. We intend to see how customers perceive these different online retail companies and what is the satisfaction level of the customers.

However, customer perception theory is an attempt to see how a customer's view of an item or administration impacts their conduct. The individuals attempt to comprehend why buyers settle on the choices they do, and how to impact these choices. This theory is utilized by advertisers when planning a campaign for an item or brand majorly to comprehend psychology in a broad sense (Flamand, 2016). Customer perception applies the idea of physical recognition to showcasing and promoting. Customer perception relates to how people structure suppositions about organizations and the stock they offer through the buys they make. Merchants apply customer perception theory to decide how their customers see them. They additionally utilize customer perception theory to create promoting and publicizing techniques proposed to hold current customers and draw in new ones (Blank, 2016). That supports e-retail websites to deliver an innovative experience for its customers and influence positive e-service quality perceptions, higher trust levels, website loyalty and positive word-of-mouth behavior (Frasquet et. al. 2015; O'Cass and Carlson, 2012). That helps to increase e-loyalty and has a positive impact on customer-related outcomes mainly word-of-mouth and willingness to pay (Srinivasan, Anderson, and Ponnavolu, 2002). Therefore, for the three e-retail merchants selected Amazon, Flipkart, and Snapdeal we have formulated our hypothesis to understand the key factors that impact customer perception towards online shopping in India.

H1: Indian customer's perception towards online shopping is not neutral towards the physical appeal of the product, the delivery time of the product, the security of the product during transit, the ease of return/replacement of the product.

In addition to this independent satisfaction factors that impact customer satisfaction in distinctive ways was initially planned by Kano (1984) in the quality management literature, alluding to Herzberg, Mausner, and Snyderman's (1959) two-factor theory of job satisfaction. Later in the 1990s researchers focussed on service quality and satisfaction using different techniques (Johnston, 1995; Gale, 1994; Vavra, 1997). The critical incident technique (Johnston, 1995) finds satisfiers, dissatisfies, and hybrid factors that contribute differently to overall satisfaction. Although consumer loyalty has abroad examination custom of more than three decades (Oliver, 1997), consensus on the three-factor structure of satisfaction level have been completed (Anderson, Fornell, and Mazvancheryl, 2004; Berman, 2005; Füller, Matzler, and Faullant, 2006; Oliver, 1997). The three-factor theory (Matzler and Sauerwein, 2002) holds that three satisfaction factors can be distinguished: (1) Basic factors (dissatisfiers) are least necessities that cause dissatisfaction if not fulfilled but rather don't lead to consumer satisfaction if fulfilled or surpassed. (2) Excitement factors (satisfiers) are the factors that increase consumer satisfaction if delivered yet don't bring about dissatisfaction on the off chance that they are not delivered. (3) Performance factors (hybrids) lead to satisfaction if performance is high and to dissatisfaction if performance is low. The three-factor structure of customer satisfaction has some vital ramifications for practice (Berman, 2005; Matzler and Hinterhuber, 1998).

Furthermore, customer satisfaction predicts trust for both infrequent and frequent online shoppers, perceived risk fully mediates the effect of trust on repurchase intentions for infrequent online shoppers (Mortimer et.al, 2016). It is contended that basic factors build up a 
business sector passage "limit". On the off chance that they are delivered at a satisfactory level, an increase in performance does not prompt an increase in customer satisfaction. Regularly, performance factors are specifically associated with customers' express needs and longings. The business of need satisfaction is not accepted by the marketers and they have created bias towards individual's needs and wishes (Alvesson, 1994). They are regularly plainly expressed and enunciated by the customer. In this way, an organization ought to be aggressive as to performance factors. Excitement factors are sudden and shock the customer. As they create "delight", an organization ought to attempt to emerge from the rest as to these characteristics. In order to analyse the difference in customer's satisfaction towards online shopping with respect to the three selected merchants - Flipkart, Snapdeal and Amazon - we have formulated the second hypothesis for online shopping of electronic goods in India.

H2: The mean of the quality of the product, cost-effectiveness, ease of product usage, delivery period, description as per order, customer support, product search, future intentions for each of Flipkart, Amazon \& Snap deal is different for at least one of the pairs of merchants.

\section{RESEARCH METHODOLOGY}

E-commerce merchants in India have tremendously increased over the last few decades. New ventures are adding up rather steadily and new e-retail merchants are finding new and innovative marketing ideas to enhance customers shopping experience and satisfaction derived from their e-retail outlet. The online shopping trend has increased in Indian markets as well giving a tough competition to the brick-and-mortar shopping experiences of the customers as well. Therefore, in this paper we have made an attempt to understand the customer's perception satisfaction they derive from the three major Electronic goods merchants in the Indian markets. For this we have selected Flipkart, Amazon, and Snapdeal as the three most competitive online merchants in the electronics segments in Indian markets. In order to determine customers' preference and satisfaction at the time of buying electronic goods through online shopping from the selected three merchants, we prepared questionnaire stating various attributes of factors that may influence the buying pattern and style of the customer. The structured questionnaire was based on Kano model (1984) of customers' satisfaction and needs. Also, Porter's Model (2008) of competitive strategy with respect to the product or services was used for electronic goods shopping through e-retail sector. The questionnaire was distributed through online 'Google forms' to Indian customers who are aware about the new trends of online shopping. The pre-test of the questionnaire was conducted and after checking for the reliability and validity of the data, we opened the questionnaire through online sources. The questionnaire was based on the likert scale of 1 to 7 with 1 as strongly disagree and 7 as strongly agree. Data was collected during December 2015. Initially, we received 116 online responses and after editing we had remove 16 responses. Thus we analyse our questionnaire with a sample size of 100 . The questionnaire probed three areas of the consumer profile/psyche: the consumer's demographic information (such as age, sex, disposable income, profession, etc.), generic factors related to customer's perception (for not doing online shopping), and satisfaction of not doing/doing online shopping for electronic goods in India. The questions were related to the dependent variables such as quality of product, cost of product, ease of product usage, product delivery period, return or replacement of product, description as per product ordered, customer support, 
product search, and future intention of buying, for the purpose of comparing the customer satisfaction for each of the e-commerce merchants namely Flipkart, Amazon, and Snapdeal. To know about the customer perception and satisfaction level for not doing online shopping, the variables such as physical appeal; delivery; security during transit; and ease of use or replacement of the product have been considered. We have developed the research questions as to what extent these variables affect the customer perception and customer satisfaction towards the online purchase of electronic goods. We have selected these three merchants (Flipkart, Amazon, and Snapdeal) because they are the market leaders in the e-commerce electronic goods retail industry in India. Also these players are relatively new in the Indian markets, yet have captured the maximum market share in the electronics online shopping segment.

To find which merchant (Amazon, Flipkart, and Snapdeal) is preferred more by Indian customers when they plan to buy electronic goods through online shopping, we have used one-way analysis of variance (ANOVA). Also for customer satisfaction towards online shopping of electronic goods in India was also analyzed. IBM SPSS software version 20 has been leveraged to analyse the data and apply the statistical methodology- t-test and ANOVA. For analysing the customer's perception towards online shopping with respect to the factors that may have an impact on buying an electronic product through e-commerce portals, we have applied t-test on the alternative hypothesis:

\section{DISCUSSION AND RESULTS}

\section{Consumer's preference for online shopping of electronic goods through e-commerce websites}

Customer perception determines the factors that affect the customer's decision to purchase online electronic goods, as long as the customer perceives the online electronic product to be valuable enough, customer perception does not get impact by any of the factors. Similar is the case with customer satisfaction. It generally creates a comparison between the different eretailers w.r.t. the factors or attributes affecting the customer satisfaction. Customer satisfaction may vary from one retailer to another for different factors.

The consumers are aware of new innovations and technologies that may help them to grow. One such example is the e-commerce websites. Customers' are aware of the online shopping portals and the different schemes they provide. Indian economy has experienced this change a few years ago. The online shopping started with purchasing books and today every product can be bought through online portals. We intended to understand the electronic goods market scenario in India and the major players preferred by the customers when they open an ecommerce site. There are three major players in the Indian markets that are market leaders in Electronics and fashion. The three identified players are Flipkart, Amazon and, Snap deal. The details of these players are shown in Table 1.

Table 1. Major e-commerce players in India as on March 2015

\begin{tabular}{|l|l|l|l|}
\hline & Flipkart & Amazon & Snapdeal \\
\hline $\begin{array}{l}\text { Year } \\
\text { commencement }\end{array}$ & 2007 & 2013 (in India) & 2010 \\
\hline CEO & Binny Bansal & Jeff Bezos & Kunal Bahl \\
\hline India Head & Binny Bansal & Amit Agarwal & Kunal Bahl \\
\hline
\end{tabular}




\begin{tabular}{|c|c|c|c|}
\hline Headquarters & Bangalore, India & Seattle, Washington & New Delhi, India \\
\hline $\begin{array}{l}\text { Type of products } \\
\text { offered }\end{array}$ & $\begin{array}{lr}\text { Ranges } & \text { from } \\
\text { electronics } & \text { to } \\
\text { fashion to home } \\
\text { appliances } \\
\text { furniture to books } \\
\text { and many more } \\
\text { Own product range } \\
\text { under the name } \\
\text { "Digiflip" }\end{array}$ & $\begin{array}{l}\text { They started as an } \\
\text { e-retailer in records. } \\
\text { Now offering } \\
\text { products ranging } \\
\text { from electronics to } \\
\text { fashion to home } \\
\text { appliances } \\
\text { furniture and many } \\
\text { more. Kindle is } \\
\text { their specialized } \\
\text { product }\end{array}$ & $\begin{array}{lr}\text { Ranges } & \text { from } \\
\text { electronics } & \text { to } \\
\text { fashion to home } \\
\text { appliances } \\
\text { furniture to books } \\
\text { and many more }\end{array}$ \\
\hline Market leader in & $\begin{array}{l}\text { Electronics } \\
\text { Fashion }\end{array}$ & $\begin{array}{l}\text { Electronics \& } \\
\text { Fashion }\end{array}$ & $\begin{array}{l}\text { Electronics \& } \\
\text { Fashion }\end{array}$ \\
\hline Market share & $44 \%$ & $15 \%$ & $32 \%$ \\
\hline Discounts/offers & \begin{tabular}{lr} 
Discount & \multicolumn{2}{c}{ coupons, } \\
promo deals $\&$ \\
offers on \\
product & categories; \\
organize & "Big \\
Billion & Days" \\
shopping & festival to \\
give & special \\
discounts & every \\
year &
\end{tabular} & $\begin{array}{l}\text { Amazon coupons, } \\
\text { promotional code \& } \\
\text { discount deals on } \\
\text { various product } \\
\text { categories; gives } \\
\text { special discounts \& } \\
\text { offers during festive } \\
\text { season and time \& } \\
\text { again }\end{array}$ & $\begin{array}{l}\text { Discount coupons, } \\
\text { discount codes on } \\
\text { all product } \\
\text { categories; gives } \\
\text { special discounts \& } \\
\text { offers during "The } \\
\text { great online } \\
\text { shopping festival." }\end{array}$ \\
\hline
\end{tabular}

1. Flipkart - It is without further ado among the best and prevalent e-retailing site working in India. Flipkart started its operations in 2007, basically with the book retailing which is the reason it is alluded to as "Amazon of India." With its exceptional achievement and certainty of investors the firm now offers extensive variety of items, including movies, music, games, mobiles, cameras, PCs, healthcare and individual items, home machines and gadgets, stationery, aromas, toys, clothes, shoes, and so on (The Flipkart Story, 2016). There are bunches of way breaking thoughts which Flipkart has effectively executed like cash on delivery, 30-day substitution arrangement, EMI choices and so forth.

2. Amazon - Amazon.com, Inc. regularly alluded to as essentially Amazon is an American electronic trade and distributed computing organization with central station in Seattle, Washington. It is the biggest Internet-based retailer in the United States. Amazon.com began as an online book-shop, later enhancing to offer DVDs, Blubeams, CDs, video downloads, MP3 downloads, book recording downloads, programming, computer games, gadgets, attire, furniture, food, toys and, jewellery. The organization likewise delivers shopper hardware-quite, Amazon Kindle digital book readers, Fire tablets, Fire TV and, Fire Phone - and is the world's biggest 
supplier of cloud base administrations. Amazon additionally offers certain low-final items like USB links under its in-house brand Amazon Basics.

3. Snap deal - Snap deal is possessed and oversaw by Wharton graduates. It was begun on 14 February 2010 as a day by day bargains stage yet extended in September 2011 to end up an online commercial centre (Gooptu, 2014). Snap deal has developed to wind up one of the biggest online commercial centre in India offering a grouping of 10 million items crosswise over various classifications from more than 100,000 vendors, delivery to 5,000 towns and urban communities in India. In March 2015, Snap deal brought actor Aamir Khan for the advancement of its site in India. Snap deal acknowledge instalment through credit card, cash on delivery, internet banking, credit on EMI basis, and so on. It additionally offers money plan to the frequent customers to make the shopping more advantageous and quicker.

From the analysis of our results, it has been observed that the customer perception towards the online shopping of electronic goods is impacted by the Physical appeal of the product only while other factors do not impact the customer's perception towards online shopping of electronic goods.

\section{Demographic profile of the consumers buying electronic goods online (respondents)}

Of all the respondents who have been asked whether they purchase the electronic goods online or not, $76 \%$ have said yes while $24 \%$ have said no. From the respondents who have purchased electronic goods online, $61 \%$ of them have purchased from Flipkart, $31 \%$ from Amazon, 23\% from Snapdeal and only 6\% have purchased from other e-commerce websites. Mobiles have emerged as the single largest category in the purchase of online electronic goods with $64 \%$ responses. Computers/Laptops have been purchased by $25 \%$ of the respondents, Television by $12 \%$, Washing machine by only $2 \%$, and none have purchased refrigerator while 19\% purchased other kinds of electronic goods. This indicates customers' preference for the purchase of electronic goods online has increased over time mainly for mobiles, and computer/laptops whereas preference for washing machines, refrigerators and other categories still need to attract more potential customers. Amongst the three merchants, we find that Flipkart is the clear winner in the Indian markets. The first mover effect in terms of associating with young minds through novel, books etc. have played for their benefits and have created their own market within young Indians.

Looking at the demographic profile of the respondents (Table 2) it was found that $58 \%$ of them were males while $42 \%$ were females. The respondents were from different age groups. $57 \%$ of the respondents were between 18-30 years of age. The respondents were having different educational qualifications. Of all the respondents, $60 \%$ were graduates, and $26 \%$ were post-graduate. $50 \%$ of the respondents were Engineers. The respondents were working with different industries in the country with work experience of even more than 25 years or no work experience at all. $38 \%$ of the respondents have been from the IT background, and $17 \%$ were from manufacturing sector (table 3). $46 \%$ of the respondents have less than 5 years of work experience. All the respondents belonged to different parts of the country with $46 \%$ of them from Delhi/NCR (table 2). The respondents were categorized into the different salary brackets with $27 \%$ of the respondents were having a salary of less than 5 lakhs/annum, $43 \%$ of the respondents were having a salary range of 5-10 lakhs/annum, and 24\% having the range of 10-20 lakhs/annum. The survey results show young customers of age 18-30 years 
are more inclined towards online shopping experience. Educational background, work experience, salary and residing places make a difference in customer's perception of buying products through online shopping especially electronic goods. Mobiles and Laptops/Computers have positively impacted the young minds who prefer to spend time on these gadgets and while exploring different websites may prefer to buy products/services provided under different schemes provided by different merchants in Indian markets. That will help business managers to revisit and, design discounts and schemes preferred mainly by the youth of India and thereby the customer satisfaction and experience through online shopping will increase further.

Table 2. Demographic characteristic of the respondents -1

\begin{tabular}{|c|c|c|c|c|c|c|c|c|c|}
\hline \multicolumn{2}{|c|}{$\begin{array}{l}\text { Gender }(n \\
=127)(\% \\
\text { of total } \\
\text { respondent } \\
\text { s) }\end{array}$} & \multicolumn{2}{|c|}{$\begin{array}{l}\text { Age group } \\
\text { (years) (\% } \\
\text { of total } \\
\text { respondent } \\
\text { s) }\end{array}$} & \multicolumn{2}{|c|}{$\begin{array}{ll}\text { Educational } & \\
\text { Qualification } & (\% \\
\text { of } & \text { total } \\
\text { respondents) } & \end{array}$} & \multicolumn{2}{|c|}{$\begin{array}{l}\text { Profession }(\% \\
\text { of total } \\
\text { respondents })\end{array}$} & \multicolumn{2}{|c|}{$\begin{array}{l}\text { Location (\% of total } \\
\text { respondents) }\end{array}$} \\
\hline $\begin{array}{l}\text { Male } \\
\text { Femal } \\
\text { e }\end{array}$ & $\begin{array}{l}58 \\
42\end{array}$ & $\begin{array}{l}18-30 \\
30-45 \\
45-60\end{array}$ & $\begin{array}{l}57 \\
23 \\
20\end{array}$ & $\begin{array}{l}\text { Undergradua } \\
\text { te } \\
\text { Graduate } \\
\text { Post } \\
\text { Graduate } \\
\text { Doctorate } \\
\text { Others }\end{array}$ & $\begin{array}{l}2 \\
60 \\
26 \\
8 \\
4\end{array}$ & $\begin{array}{l}\text { Teacher } \\
\text { Engine } \\
\text { er } \\
\text { Lawyer } \\
\text { Others }\end{array}$ & $\begin{array}{l}6 \\
50 \\
1 \\
43\end{array}$ & $\begin{array}{l}\text { Delhi } \\
\text { Mumbai } \\
\text { Kolkata } \\
\text { Bangalore } \\
\text { Others }\end{array}$ & $\begin{array}{l}46 \\
2 \\
18 \\
12 \\
22\end{array}$ \\
\hline
\end{tabular}

Table 3. Demographic characteristic of the respondents - 2

\begin{tabular}{|c|c|c|c|c|c|}
\hline \multicolumn{2}{|c|}{$\begin{array}{l}\text { Industry }(\% \text { of total } \\
\text { respondents })\end{array}$} & \multicolumn{2}{|c|}{$\begin{array}{l}\text { Work Experience (years) } \\
\text { (\% of total respondents) }\end{array}$} & \multicolumn{2}{|c|}{$\begin{array}{l}\text { Annual Income (in } \\
\text { rupees per lakhs) (\% of } \\
\text { total respondents) }\end{array}$} \\
\hline Manufacturing & 17 & Below 5 & 46 & Below 5 & 27 \\
\hline Information & 38 & $5-15$ & 42 & $5-10$ & 43 \\
\hline Technology & 5 & $15-25$ & 1 & $10-15$ & 18 \\
\hline Banking & 2 & Above 25 & 11 & $15-20$ & 6 \\
\hline Financial Services & 38 & & & Above 20 & 6 \\
\hline Others & & & & & \\
\hline
\end{tabular}

\section{Empirical analysis}

In order to understand customer satisfaction better and customers' perception and buying experience of electronic goods from different e-retailing merchants in India and their experience, we have formulated few hypotheses.

Customer Perception - One sample hypothesis testing (t-test) has been conducted to know about the customer perception towards the online shopping of electronic goods in India for each of the identified variables. The Kolmogorov-Smirnov test and Shapiro-Wilk test of normality have been applied on the sample collected. All the variables under study were 
normally distributed. Hence to analyze which of the variables affect the online shopping behavior of the customers we have applied t-test. The results are presented in the table 4 .

Table 4. Results of Hypothesis analyzed

Customer's perception towards online shopping for electronic goods

\begin{tabular}{|c|c|c|}
\hline & Hypothesis & $\begin{array}{l}\text { One-sample t-test }-p \text {-value (Decision to } \\
\text { reject Null Hypothesis at } 5 \% \text { level of } \\
\text { significance) }\end{array}$ \\
\hline H1 & $\begin{array}{l}\text { Indian customer's perception towards } \\
\text { online shopping is not neutral } \\
\text { towards the physical appeal of the } \\
\text { product, the delivery time of the } \\
\text { product, the security of the product } \\
\text { during transit, the ease of } \\
\text { return/replacement of the product. }\end{array}$ & $\begin{array}{l}\text { Physical appeal of the product }-0.003^{* *} \\
\text { Delivery time for the product }-0.564 \\
\text { Product security during transit }-0.424 \\
\text { Ease of return /replacement of the product - } \\
0.369 \text {. }\end{array}$ \\
\hline \multicolumn{3}{|c|}{ Customer's satisfaction towards Flipkart, Amazon and, Snap deal } \\
\hline & Hypothesis & $\begin{array}{l}\text { One way Analysis of Variance (ANOVA) - } \\
\text { p-value (Decision to reject Null Hypothesis } \\
\text { at } 5 \% \text { level of significance) }\end{array}$ \\
\hline $\mathrm{H} 2$ & $\begin{array}{l}\text { The mean of the quality of the } \\
\text { product, cost effectiveness, ease of } \\
\text { product usage, delivery period, } \\
\text { description as per order, customer } \\
\text { support, product search, future } \\
\text { intentions for each of Flipkart, } \\
\text { Amazon \& Snapdeal is different for } \\
\text { at least one of the pairs of merchants. }\end{array}$ & $\begin{array}{l}\text { Quality of the product }-0.000^{* *}(\mathrm{~F}-\text { Ratio }= \\
18.436) \\
\text { Cost-effectiveness }-0.011^{* *}(\mathrm{~F}-\text { Ratio }= \\
4.608) \\
\text { Ease of product usage }-0.000^{* *}(\mathrm{~F}-\text { Ratio }= \\
14.207) \\
\text { Delivery period }-0.000^{* *}(\mathrm{~F}-\mathrm{Ratio}=9.003) \\
\text { Description as per order }-0.000^{* *}(\mathrm{~F}-\mathrm{Ratio} \\
=10.197) \\
\text { Customer support }-0.000^{* *}(\mathrm{~F}-\mathrm{R} \text { atio }= \\
11.791) \\
\text { Product search }-0.000^{* *}(\mathrm{~F}-\mathrm{Ratio}=20.146) \\
\text { Future intention to buy }-0.122(\mathrm{~F}-\mathrm{Ratio}= \\
2.121)\end{array}$ \\
\hline
\end{tabular}

Customer Satisfaction - One-way analysis of variance (ANOVA) has been conducted to know about the mean of the dependent variable, and to analyze and compare the same for each of the three merchants namely Flipkart, Amazon, and Snap deal. Normality test data was found to be normally distributed for each of the factors. Consequently, we conducted ANOVA. In case the mean of the dependent variable is found to be different for any pair of merchants, we have performed the multiple comparison test, named Tukey's test. This test helps to determine the rankings concerning the particular dependent variable among the three merchants based on the relative difference in the means for that dependent variable. This 
helps in determining the degree of customer satisfaction for each of these three merchants. The results of ANOVA and Tukey's test are presented in Table 4.

It is noted that the mean of all the factors except for future intention to buy the product (for which the mean is same for each of Flipkart, Amazon and, Snap deal) is different for at least one of the pairs of merchants namely Flipkart, Amazon and, Snap deal. It indicates that customer satisfaction is more or less same for each of the three merchants w.r.t. the future intention of buying the product from them. For the return/replacement of the product, the data set was not found to be homogenous (because of significant value or p-value < 0.05 ) due to which ANOVA is not applicable in its case. To find out the degree of customer satisfaction towards all of the other factors for each of these merchants Tukey's test was applied. The results showed that the customer satisfaction w.r.t. quality of the product, cost-effectiveness, ease of product usage, delivery period, product received as per description ordered and the product search is the highest for Flipkart and the lowest for Snap deal. Whereas the customer satisfaction w.r.t. customer support is the highest for Amazon and the lowest for Snap deal. Hence, it can be inferred that overall, the average rate of customer satisfaction is the highest for Flipkart and the lowest for Snapdeal pertaining to the purchase of electronic goods in India via these e-commerce merchants.

\section{MANAGERIAL IMPLICATIONS}

The electronic shopping through e-commerce websites has become popular yet, the traditional ways of shopping dominating the Indian markets. It may be because the customers are not fully aware about the online shopping benefits, discounts, and offers provided. Although, few customers are aware of these different retail websites that are not willing to buy these products. That may be because Indian customers mostly prefer to look at the physical appearance and the design of the product. However, the purchasing power of these customers has increased in the recent past but, they still ensure that they get the value for what they spend. Moreover, there is a negative relationship between the need for social interaction and the propensity to engross in internet transactions by the customers. However, there is the positive relationship between the convenience and the frequency and size of purchases on the internet (Swaminathan et. al. 1999). The companies are present in various discussion forums, blogs, and social media sites to increase online transactions of electronic goods.

From a managerial perspective, it is noteworthy that e-retailing of electronic goods is on both customer perception and customer satisfaction. Furthermore, the results also indicate the fact that some of the variables selected influence the customer perception and satisfaction w.r.t. to the online shopping of electronic goods. Therefore, online retailers should realize they are lacking in the performance of some of their attributes which are the necessary drivers to change the customer perception towards online electronic goods and to increase the level of customer satisfaction towards their e-retailing. This study can provide a lot of insights as to how to look at the e-commerce business from the customer's point of view. E-commerce companies can implement the strategies to grow their businesses to achieve a higher level of customer satisfaction through this study. That can also be beneficial to the society as a whole as the people will become aware of the shopping trends in the e-commerce business. The government can support the e-commerce business to grow its customer base by reaching out to the masses and in turn can be itself benefitted as well. 


\section{CONCLUSIONS AND RECOMMENDATIONS}

The e-commerce market is very dynamic. Some of the key players have been present since long, but have captured the larger chunk of market share in the last couple of years only. One has to keep analysing the changing market trends to remain in the competition. Many players have emerged with the success of the e-commerce industry in India. That poses a severe threat \& enhances competition for the existing players. In totality, the market capitalization of Flipkart is 15 billion dollars which is the highest among all the e-commerce players in India. Moreover, customer perception towards online shopping has influenced by the physical appeal of the product which has been proved by the t-test conducted above. At least one pair of merchants (Flipkart, Amazon and, Snap deal) is different in regards to the quality of the product, cost-effectiveness, ease of product usage, delivery period, product received as per description ordered product search and the customer support.

As per the degree of customer satisfaction pertaining to the online purchase of electronic goods, our findings suggest that Flipkart as the first rank holder, Amazon as the second and Snap deal as the third. So, if Snap deal wants to remain competitive in the Indian market, it has to revamp its user interface and better execute its operational activities to match up to the level of Flipkart.

\section{References}

Anderson, E.W., Fornell, C., and Mazvancheryl, S.K. (2004) "Customer satisfaction and shareholder value." Journal of Marketing, Vol.68, No.4, pp.172-185.

Alvesson, M., (1994) "Critical theory and consumer marketing." Scandinavian journal of management, Vol.10, No.3, pp.291-313.

Bama, M. S., and Ragaprabha, M. (2016) "Satisfaction on Online Shopping-A Study with Special Reference to Pollachi Taluk." International Journal of Multidisciplinary Research and Modern Education, Vol.2, No.1, pp.2454 - 6119.

Berman, B. (2005) "How to delight your customers." California Management Review, (Fall), pp.129-151.

Bhandari, N. (2015) "Online Commerce: The Future of Business." University Business School, Punjab University, Chandigarh, India. http://www.cbsmohali.org/img/04.pdf last assessed on March 10, 2016.

Blank, C. (2016) "Consumer Perception Theory." http://smallbusiness.chron.com/consumerperception-theory-40176.html retrieved on March 6, 2016.

Bolar, K., \& Shaw, B. (2015) "End-user Acceptance of Online Shopping Sites in India.” Journal of Internet Banking and Commerce, Vo.20, No.2, pp.1-18.

Chan, G., Cheung, C., Kwong, T., Limayem, M., \& Zhu, L. (2003) "Online consumer behavior: A review and agenda for future research.” BLED 2003 Proceedings, Vol.43.

Chatterjee, D., \& Ghosal, I. (2014) "E-Commerce in India Future and its Perspective: A Study." International Journal of Scientific Research and Engineering Studies, Vol.1, No.4, pp.25-31.

Bhakkad, D. (2012) "Changing Scenario of Business and E-commerce." http://www.newagepublishers.com/samplechapter/001390.pdf, retrieved on May 16, 2016. 
Eriksson, T., (2014) "Processes, antecedents and outcomes of dynamic capabilities," Scandinavian Journal of Management, Vol.30, No.1, pp.65-82.

Flamand, L. "Consumer (2016) Perception Theory." http://www.ehow.com/about_6561090_consumer-perception-theory.html retrieved on March 26, 2016.

Frasquet, M., Ruiz-Molina, M.E. and Molla-Descals, A., (2015) "The role of the brand in driving online loyalty for multichannel retailers." The International Review of Retail, Distribution and Consumer Research, Vol.25, No.5, pp.490-502.

Füller, J.; Matzler, K.; and Faullant, R. (2006) "Assessing the asymmetric impact of satisfaction factors on overall customer satisfaction- The case of Alpine snowboard areas." Annals of Tourism Research, Vol.33, No.4, pp.1159-1163.

Gadgets Now. (2014) "Online Shoppers in India to cross 200 million by 2016." Gadgets Now, Nov. 20, 2014, http://www.gadgetsnow.com/tech-news/Online-shoppers-inIndia-to-cross-100-million-by-2016-Study/articleshow/45217773.cms, retrieved on September 10, 2016.

Gale, B. T. (1994). Managing customer value. New York.

Gooptu, Biswarup. (2014) "Snapdeal co-founder Kunal Bahl: A rising star of India's ecommerce space." The Economic Times. Published on 28 February 2014. Retrieved February 16, 2016.

Gulam, D., and Badhusha, M. (2015) “A study of consumers' purchasing decision towards online shopping with special reference to students of selected colleges in Tiruchirappalli city." International Journal of Interdisciplinary Research, Vol.2, No.5.

Gupta, M. T., \& Gandhi, D. (2015) "Online Market-Future of Shopping In India." International conference on Science, Technology and, Management, YMCA, New Delhi (India), Published 1 Feb 2015. Retrieved February 16, 2016.

Gupta, S., and Bansal, E. (2016) "Consumer Orientation towards Online Buying Via Social Media Platforms." International Journal of Scientific Research and Education, Vol.4, No.1.

Harris, L. and Dennis, C., (2002) Marketing the e-Business (Vol. 2). Psychology Press.

Herzberg, F.; Mausner, B.; and Snyderman, B.B. (1959) “The motivation to work." Wiley, New York (1959).

Invertor Words. (2016) "Bricks-and-Mortar." http://www.investorwords.com/580/bricks_and_mortar.html_last assessed on February 8, 2016.

Investopedia. (2016) "Brick and Mortar." http://www.investopedia.com/terms/b/brickandmortar.asp last assessed on February 8, 2016

Jasper, C.R. and Waldhart, P. (2013) "Internet and distance channel use and European consumer complaint behavior." The International Review of Retail, Distribution and Consumer Research, Vol.23, No.2, pp.137-151.

Johnston, R. (1995) "The determinants of service quality: Satisfiers and dissatisfiers." International Journal of Service Industry Management, Vol.6, No.5, pp.53-71. 
Kano, N. (1984) “Attractive quality and must be quality." Hinshitsu (Quality), Vol.14, No.2, pp.147-156.

Kolesar, M.B. and Wayne Galbraith, R., (2000) "A services-marketing perspective on eretailing: implications for e-retailers and directions for further research." Internet Research, Vol.10, No.5, pp.424-438.

Kumar, V. R. (2015) “Online Retail in India-A disruptive force.” Samvad Journal, Vol.9, March 2015.

Lee, K.S. and Tan, S.J., (2003) "E-retailing versus physical retailing: A theoretical model and empirical test of consumer choice." Journal of Business Research, Vol.56, No.11, pp.877-885.

Manjunatha, S. (2013) "A Sociological Study on the Emergence and Growth of Online Shopping in India." International Journal of Management and Social Sciences Research, Vol.2, No.8, pp. 62-64.

Malik, G., \& Sachdeva, H. (2015) "Impact of sales promotion technique used by online dealers on consumers." International Journal of Applied Sciences and Management, Vol.1, No.1, pp.63-78.

McDonagh, P. and Prothero, A., (2014) "Sustainability marketing research: Past, present and, future," Journal of Marketing Management, Vol.30, No.11-12, pp.1186-1219.

McGoldrick, J., Stewart, J. and Watson, S., (2002) "Understanding HRD: a research based approach." International Journal of Human Resources Development and, Management, Vol.2, No.1-2, pp.17-30.

Matzler, K., and Hinterhuber, H.H. (1998) "How to make product development projects more successful by integrating Kano's Model of customer satisfaction into quality function deployment." Technovation, Vol.18, No.1, pp.25-38.

Matzler, K., and Sauerwein, E. (2002) "The factor structure of customer satisfaction: An empirical test of the importance grid and the penalty-reward-contrast analysis." International Journal of Service Industry Management, Vol.13, No.4, pp.314-332.

Mortimer, G., Fazal e Hasan, S., Andrews, L. and Martin, J., (2016) "Online grocery shopping: the impact of shopping frequency on perceived risk." The International Review of Retail, Distribution and Consumer Research, Vol.26, No.2, pp.202-223.

Mulhern, Francis J. (1997) "Retail marketing: From distribution to integration." International Journal of Research in Marketing, Vol.14, pp.103-124.

O'Cass, A. and Carlson, J. (2012) “An e-retailing assessment of perceived website-service innovativeness: Implications for website quality evaluations, trust, loyalty and, word of mouth." Australasian Marketing Journal, Vol.20, No.1, pp.28-36.

Oliver, R. L. (1997) "Satisfaction-A behavioral perspective on the customer." New York.

Overmars, S. and Poels, K., (2015) "How product representation shapes virtual experiences and re-patronage intentions: the role of mental imagery processing and experiential value." The International Review of Retail, Distribution and Consumer Research, Vol.25, No.3, pp.236-259.

Porter, M.E. (2008) "The Five Competitive Forces That Shape Strategy." Harvard Business Review, Vol.86, No.1, pp.25-40. 
Prashar, S., Sahay, V., \& Panda, D. (2014) "Factors affecting selection of online buying website: an analytical study among the Indian youth." International Journal of Intercultural Information Management, Vol.4, No.4, pp.247-263.

Rao, S., Goldsby, T. J., Griffis, S. E., \& Iyengar, D. (2011) "Electronic Logistics Service Quality (e-LSQ): Its Impact on the Customer's Purchase Satisfaction and Retention." Journal of Business Logistics, Vol.32, No.2, pp.167-179.

Richa, D. (2012) "Impact of demographic factors of consumers on online shopping behaviour: A study of consumers in India." International Journal of Engineering and Management Sciences, Vol.3, No.1, pp.43-52.

Roy Dholakia, R., \& Uusitalo, O. (2002) "Switching to electronic stores: consumer characteristics and the perception of shopping benefits." International Journal of Retail \& Distribution Management, Vol.30, No.10, pp.459-469.

Sharma, N. V., \& Khattri, V. (2013) "Study of online shopping behavior and its impact on online deal websites.” Asian Journal of Management Research, Vol.3, No.2, pp.394405.

Sheopuri, A., \& Sheopuri, A. (2015) "New Era of Online Shopping: Opportunities Ahead in India." International Journal of Commerce, Business and, Management, Vol.4, No.2, pp.1048 -1054.

Srinivasan, S.S., Anderson, R. and Ponnavolu, K. (2002) "Customer loyalty in e-commerce: an exploration of its antecedents and consequences." Journal of Retailing, Vol.78, No.1, pp.41-50.

Swaminathan, V., E. Lepkowska-White and B.P. Rao. (1999) "Browsers or Buyers in Cyberspace? An Investigation of Factors Influencing Electronic Exchange." Journal of Computer-Mediated Communication, Vol.5, No.2.

Swoboda, B., Weindel, J. and Schramm-Klein, H., (2016) "Crosswise and reciprocal interdependencies within retailers' multichannel structures." The International Review of Retail, Distribution and Consumer Research, pp.1-28.

Tejaswi, M.J. (2013) "Flipkart goes for fashion branding", http://timesofindia.indiatimes.com/business/india-business/Flipkart-goes-for-fashionbranding/articleshow/19832631.cms, May 2, 2013, Retrieved on March 1, 2016.

The Flipkart Story. (2016) http://www.flipkart.com/about-us retrieved on February 8, 2016.

Vadivu, T. S. (2015) "A Study on Customer Satisfaction Towards Online Shopping." Sumedha Journal of Management, Vol.4, No.2, pp.4-15.

Voropanova, E. (2015) "Conceptualizing smart shopping with a smartphone: implications of the use of mobile devices for shopping productivity and value." The International Review of Retail, Distribution and Consumer Research, Vol.25, No.5, pp.529-550.

Vavra, T. G. (1997) "Improving your measurement of customer satisfaction-A guide to creating, conducting, analyzing, and reporting customer satisfaction measurement program." Milwaukee.

Wei, Y., Straub, D.W. and Poddar, A., (2011) "The power of many: an assessment of managing internet group purchasing." Journal of Electronic Commerce Research, Vol.12, No.1, pp.19. 
Yu, W. and Ramanathan, R. (2012) "Retail service quality, corporate image and behavioural intentions: the mediating effects of customer satisfaction." The International Review of Retail, Distribution and Consumer Research, Vol.22, No.5, pp. 485-505.

Zaveri, B. 2004. "Online vs. Offline Shopping Activities: of Female Internet Users in.” DIAS Technology Review, 64.

Zorayda, R. A. 2003. E-commerce e-business. 